Annemie Dillen \& Didier Pollefeyt

Catholic University of Leuven, Belgium

\title{
Catechesis Inside Out A Hermeneutical Model for Catechesis in Parishes
}

\section{Abstract}

Parochial catechesis in Belgium, especially in Flanders as the Dutch-speaking part of Belgium, is confronted with a lot of challenges. This text deals with three main thematic clusters. The first cluster centres on the relation between 'Christianity' and 'culture' and its consequences for the content and the method of the catechesis. In a context where Christianity and culture are no longer intrinsically linked to each other, new models of catechesis have to be found. The authors propose a 'hermeneutical model of catechesis', whereby many elements of the surrounding culture and of the faith tradition(s) are confronted with each other in a multidimensional way, challenging each other. In this vision, religious truth is not a set of dogmas that should be transmitted, but an open and 'utopian' search process that asks for new questions time and again. From a didactical as well as from a theological perspective this hermeneutical model offers new opportunities for catechesis. The second cluster can be summarized as 'life-long' and 'life-wide' learning. The authors argue that is it necessary to create vertical (intergenerational) and horizontal (among a generation or a specific group) networks dealing with religious communication. Thereby they propose a specific church organisation with lots of possibilities for cooperation between different parochial groups. The title of the article, catechesis inside out, refers to the vision that religious communication is not only a task inside church communities. The authors argue for open church communities daring to speak with people that hold to different world views. The second thematic cluster also deals with the organisation of the catechesis and more specifically with the question of the target group or the age of those who are catechised. In a third movement the article deals with questions about finding 'good' catechists. At the end of the text the 


\section{The Person and the Challenges \\ 152

authors offer a summarizing reflection on the art work 'Daughters of Eve', which contains the main arguments they have dealt with.

\section{Keywords}

Catechesis, culture, hermeneutics, parish, intergenerational learning.

\section{Introduction}

In this text we will take on a number of challenges facing parochial catechesis in Belgium. We will primarily focus on the Flemish situation as this is best known to us. Whenever the various needs, questions and challenges concerning contemporary 'catechesis' are mapped out it is noticeable that three large thematic clusters arise. The first cluster is to be found around the question concerning the relation between 'Christianity' and 'culture'. This question is very important in regard to the content and method used in catechesis. The second cluster may be summarized under the title 'lifelong and life-wide learning'. This is concerned with looking for possibilities to create vertical and horizontal 'networks'. The focus here is on the church, the specific type of church involved and the possible co-operative links that could be developed. This thematic cluster also includes issues around the organisation of the catechesis, especially the question of the target group and the ages of the catechists. The third and final cluster addresses the question of finding good catechists. It becomes a very difficult, if not unattainable, task to create a vision for good catechesis without having people who engage with it responsibly. In the conclusion we offer a summarizing look at the whole catechetical event by means of a visual aid.

\section{Catechesis between Christianity and culture}

The diocesan agents responsible for catechesis in Belgium are concerned about 'good catechesis' that connects with people today. Such a 'connection' has unfortunately not been a straightforward affair for a long time. For several decades now people have spoken about a 'Tradierungskrise des Glaubens'. And this 'crisis' does not seem over yet. The linear passing down of tradition still works in some cases today, but in many others it no longer suffices or only

\footnotetext{
${ }^{1}$ E. Feifel \& W. Kasper (eds.), Tradierungskrise des Glaubens, München 1987, Lit Verlag.
} 
temporarily did so. Many catechists experience a high level of frustration when twelve year old children appear to turn their backs on the church, so to speak, following their confirmation. Against this background it is very important that we ask the question 'what must/can we bring to the content of catechesis?'. We could also ask the question 'how can we get people to take catechesis?' or 'how can we turn the tide with some strategic changes?'. Happily other more fundamental questions are also asked and the challenges lying before catechesis are not only seen in terms of a 'new packaging' but also in terms of a 'new content'. In order to obtain some insight on possible answers to these challenges we will now present a historical sketch of the evolutions regarding culture and catechesis which offers an interesting perspective in its own right.

\subsection{Evolutions in the field of culture and catechesis: perspectives on method and content}

Until the nineteen-fifties our culture was imbued with Christianity. The question of how faith could be communicated was not really an issue, it was a given. Children grew up in a Catholic world and the whole society made sure that the Christian socialization carried on naturally. In such a context faith was passed on to individuals from above and from a distance and these individuals were then charged with 'internalising' it. This was a deductive approach to religious education and catechesis.

However, by the 70s it was observed that 'faith' and 'culture' were growing ever more apart. People spoke about secularization. It was hoped that the growing gap between faith and the church on the one hand and the socio-cultural environment on the other could be closed by means of catechesis. It was further hoped that by connecting to the lifestyle and experiences of people one could build a bridge to the faith. This vision was part of an 'anthropological turn' in theology. In this perspective theology was not seen as something abstract but about everyday life. Such an approach worked inductively, arising from out of people's own experiences. Central to it was the concept of 'correlation': one tried to make the link between faith and life much clearer.

It was assumed that the ensuing conversations and exchange of experiences that reflected on various things out of the catechetical participants' own lives and from society in general should 'lead somewhere', namely to a 'faith factor' that was to be 'learned'. Many catechetical manuals for both the first communion and confirmation started from a 'human aspect' in order to end up at 'the Christian tradition'. In this approach, however, the understanding of the 'truth' as presented in the 'content' is rather static. Children often found it predictable where the 


\section{The Person and the Challenges \\ 154

catechetical theme would lead to. Nonetheless, until today both theological and educational use continues to be made of the 'correlation paradigm'2. Human experience and theological content are still associated with each other and connected seemingly seamlessly. For example, the human experience of 'bullying' is often employed as the perfect illustration to understand the Bible's teaching about 'the mote and the beam'.

Despite criticism raised against the correlation paradigm in the eighties and nineties from both a theological and a religious education point of view, the inductive correlation model continues to receive a considerable amount of attention in Flanders ${ }^{3}$. The main criticism raised against this model was that it would reduce faith to something purely 'human', to merely reflecting common human values. The element of mystery, the idea of transcendence, the 'distinct otherness' of the faith would be totally absorbed by what was 'understandable' from the sole standpoint of human experience. People would not be challenged to really critically question themselves and their own beliefs by what 'comes from elsewhere'. Because of this the opportunity for people to grow from out of the riches of the Christian faith would be to a large extent left untapped. Another criticism levelled was the predictability of the method which was seen to lead to boredom since it no longer generated interest in what in fact was 'interesting' in the Christian faith. A further critique was that there was often no real mutual critical inquiry between 'faith' and 'life' taking place. Because 'harmony' and 'agreement' between the two was so essential, few (reciprocal) critical questions were asked. In a sense this perspective on 'the truth of the tradition' is very similar to that of the previous model - although here the tradition often moves more into the background.

The real problem with the correlation method is that it 'works' fairly well only as long as Christian culture is still present in society. This presence is now seriously weakened. For many, establishing the relationship between 'faith' and 'life' is not so obvious and if this link is made by a catechist it often comes across as somewhat forced. It is therefore important that catechesis also pays attention

${ }^{2}$ G. Baudler, Korrelationsdidaktik. Leben durch Glauben erschließen. Theorie und Praxis der Korrelation von Glaubensüberlieferung und Lebenserfahrung auf der Grundlage von Symbolen und Sakramenten, Paderborn 1984, Schöningh.

3 See for example L. Boeve, Beyond Correlation Strategies. Teaching Religion in a Detraditionalised and Pluralised Context: A Playground for Social-Cultural and Theological Renewal, in: H. Lombaerts \& D. Pollefeyt (eds.), Hermeneutics and Religious Education, Leuven 2004, Peeters; R. Englert, Die Korrelationsdidaktik am Ausgang ihrer Epoche. Plädoyer für einen ehrenhaften Abgang, in: G. Hilger \& G. Reilly (eds.), Religionsunterricht im Abseits? Das Spannungsfeld Jugend, Schule, Religion, München 1993, Lit Verlag, p. 97-110. 
to the fact that the move towards faith from human experience is not a given. It is not automatic but always requires a leap of faith. This faith also repeatedly asks those who already strongly identify with it for 'lively input' so that moments of doubt are not excluded but, in fact, are seen as necessary to feed a belief that is not 'finished', 'perfect' or 'proud'. It is therefore important in catechetical formation, especially when dealing with a relatively uniform group of believers, that the crossing from 'life' to 'faith' is not presented too obviously. A realistic faith also gives space for searching, for a faith that is anchored in a basic trust dares to constantly and critically question the truths of the faith as well as to 'dust down' one’s own life and one’s own faith.

\subsection{Three models for dealing methodologically and substantively with the tension between faith and culture}

The gap between Christianity and culture has continued to grow since the advent of the correlation model. It does not appear that an inductive correlation catechesis has managed to bring people to a greater life of faith. Today we face the task of how to deal with the almost unbridgeable gap between society and the Christian faith. Generally speaking, three possible solutions may be distinguished.

A first possibility is to resolutely choose for the side of faith and to illustrate this by one's own effort and ability. We can also refer to this method by the French term 'proposer la foi'. In this approach the life experiences of people are not really thematized as such. Rather it is hoped that by presenting the faith and making the effort to explain the faith-story's own rationality people will come to see its significance for their lives. One of the underlying viewpoints behind this approach is the notion that it is essential in our pluralized society that Christians make it very clear what they stand for and that they do not blend into the crowd as 'gray mice'. The ecclesial image associated with this approach tends to be that of an 'elite-church' that sets clear conditions in terms of what it means to believe.

From this perspective catechesis is seen as the 'transfer of tradition and beliefs'. This track offers a fairly direct response to the often-heard comment that children, adolescents and adults know nothing of the Christian faith. It is claimed that they hardly know that there are four evangelists, that they seem never to have heard of the name of Paul, that the feast of Pentecost means nothing for them and so on. To cope with such 'ignorance' it appears logical to present the faith in a very clear way in order to highlight its truth. It is notable that the catechism was undoubtedly seen as a means to achieve this objective in the past. In the 60 s the personal testimony of the catechist's faith became common place, 
outlining the authenticity of a lived faith instead of dry doctrine ${ }^{4}$. In both cases the catechesis was rather deductively understood, from top to bottom, that is from the general fixed truth to the concrete human person. Even today voices are raised in support of placing 'tradition' and 'faith content' at the heart of catechesis. 'Faith content' and 'tradition' thereby receive the connotation of being a 'hard truth' as an antidote to the relativism of 'everyone putting his or her own faith together as they please'. For some this paradigm sounds very attractive but for many others and certainly for many catechists, it is not at all appealing, partly because the link with a person's life experiences is far from explicit.

Concrete applications of this model are still often to be found at parent evenings where parents of the first communicants receive a theoretical explanation about 'what is the Eucharist?' or 'what is Christian faith?'. Usually speaking such proposals are primarily based on and emphasize Christian doctrine rather than people's experiences.

An alternative way to deal with the large gap between faith and culture is to choose for the other pole, that is people's life experiences. This method is in a certain sense a continuation of the inductive approach of the 70s, except that the search for suitable correlations becomes increasingly difficult and attempts to bring in the faith are often abandoned. In this case catechesis becomes primarily a reflection about a person's own life, the world, social problems, or values and norms without much reference to the story of faith.

Letting the faith 'penetrate through' is very difficult in a secularized context because of unbelief and indifference. Catechesis then finds itself on a par with a casual 'talking shop', without bringing much philosophical reflection or experience to bear.

A faith talk is sometimes filled in with the 'sharing of authentic experiences'. Yet "instead of being an (admittedly indispensable) reference point during the learning process, the mutual affirmation of each other's personal experiences in many parish catechesis has become an end in itself"5. This form of catechesis is to be contrasted with the deductive model outlined above. In this instance, the contribution of the participants is very high and the 'objective presentation of the faith' is pushed to the background in favour of people's own experiences. The church image associated with this model is that of a 'service church', a church

${ }^{4} \mathrm{~F}$. Pajer, L'enseignement scolaire de la religion en Europe. Vue panoramique d'une mutation, in: J. Bulckens \& H. Lombaerts (eds.), L'enseignement de la religion catholique à l'école secondaire. Enjeux pour la nouvelle Europe, Leuven 1993, Peeters, p. 31-57.

${ }^{5} \mathrm{H}$. van den Bosch, De toekomst van de parochiecatechese, in: S. Hellemans, W. Putman, J. Wissink (eds.), Een kerk met toekomst? De katholieke kerk in Nederland 1960-2020, Zoetermeer 2003, Meinema, p. 128. 
that responds to all inquiries from people without bothering them with its own Christian identity or offering them more than what they ask for directly.

A third possible approach tries in a certain sense to keep the middle ground between the other two and strives for a kind of 'osmosis' between faith and culture $^{6}$. Here one can speak of an 'osmotic church image'. Osmosis is the Greek word for 'thrusting' and figuratively means 'interpenetration'. When applied to this context of faith and culture we mean that a reciprocal exchange between faith and culture takes place but no fusion. As in the biological process of osmosis substances pass through from both sides, but both the faith and the culture preserve their own identity. Such a perspective on religious communication assumes that there is no automatic mono-correlational relationship between faith and culture, but that in different ways the various perspectives arising from different contexts can be confronted with each other without the one vision 'swallowing up' the other. Faith and culture should not necessarily be brought into harmony, but may also collide and raise mutually critical questions. This perspective may be further identified with the term 'hermeneutical model'. Hermeneutics refers to a multitude of processes of interpretation in different fields and offers a critical correction to correlation thinking but not in the sense that the 'correlation method' is rejected outright, but rather that a critical multi-correlational approach is sought.

\subsection{Explanation of the 'hermeneutical model' as 'critical confrontation and enrichment' between faith and experience}

We are persuaded that the hermeneutical model offers us the best opportunity to deal further with the gap between Christianity and culture that characterizes our society. Let us explain. The hermeneutical model attempts to integrate the positive elements of both the deductive and inductive models'. Here 'interpretation', 'persistent questioning' and 'critical reflection' are all central. Its theological perspective is that the truth of the faith tradition is more of an on-going search

${ }^{6}$ Ibid., p. 136.

7 See also D. Pollefeyt, Het leven doorgeven. Religieuze traditie in de katholieke godsdienstpedagogiek, in: H. Van Crombrugge \& W. Meijer (eds.), Ontwikkelingen en toekomstperspectieven. Pedagogiek en traditie, opvoeding en religie, Tielt 2004, Lannoo, p. 133149. Hermeneutics' plays an important role in reflections on contemporary religious education. See the recent doctoral dissertation, J. Maex, A Hermeneutical-Communicative Concept for Teaching Religion. Fundamental-Theoretical and Empirical Research. Unpublished doctoral thesis in theology, Leuven 2003. The method and the background of this concept is also fruitful for catechesis. 
with an openness to the future rather than something stuck in the past ${ }^{8}$. Precisely because of this understanding space is created in both novel and surprising ways to deal with the twin issues of life experience and beliefs. A well coached bibliodrama where the supervisor's own perspective is not present and where he or she leaves room for a series of possible interpretations is an example of such a catechesis. In a hermeneutical catechesis as many different 'stimulants' as possible should be used, such as newspaper articles, images, photos, videos, TV shows, bible fragments, faith testimonies, elements from other world religions and so forth. This form of catechesis is based on an 'active didactical method' where children, youth and adult listeners are not passive but instead actively contribute on a variety of levels to the learning, interpretation and communication process $^{9}$.

Today we are living in a multicultural and multireligious world and face many different perspectives. Children, adolescents and adults may also ask themselves questions about the customs and rituals of Muslims, Jews, followers of Wicca and so forth. It is important that there is room given for such questions within a catechetical process and that answers to them may be sought for together. This openness and diversity of perspectives and stimulants makes the question of finding the 'core' of what should be addressed inside the catechesis even more pressing. Within catechetical learning (which in fact is a lifelong process) there should be room for the Creed, the Ten Commandments, the seven sacraments and the Our Father. These classical catechetical elements also belong in a hermeneutical learning process and ought to be introduced - though not on a 'take it or leave it' basis, but as a stimulant wherewith participants can critically confront themselves throughout the catechetical process. There must naturally be room, therefore, for various interpretations in regard to the central content of the catechesis.

The primary goal of this third model is to help catechetical participants clarify their own positions and their own vision of faith in confrontation with the plurality of different views both within and without the Christian tradition. For those who explicitly classify themselves as believers this may be an incentive to develop

${ }^{8}$ I. Cornu \& D. Pollefeyt, Religieus opvoeden tussen openheid en geslotenheid. Bijbels geloof in een Babelse wereld, in: D. Pollefeyt (ed.), Leren aan de werkelijkheid. Geloofscommunicatie in een wereld van verschil, Leuven 2003, Peeters, p. 56-58; R. Bieringer, The Normativity of the Future. The Authority of the Bible for Theology, "Bulletin ET. Zeitschrift für Theologie in Europa" 8 (1997), p. 52-67.

${ }^{9}$ See also the theological and pedagogical reflection on 'action learning' by Paul Vermeer in P. Vermeer, New Ways to Learn Religion in School. Learning Religious Traditions in View of Religious Identity Formation, in: H. Lombaerts \& D. Pollefeyt (eds.), Hermeneutics and Religious Education, Leuven 2004, Peeters. 
a 'resilient' and 'durable' faith in the midst of a pluralistic world. For those who rather hesitate or doubt the hermeneutical model can be a way to delve into the backgrounds of their own perspectives and that of certain other Christian views, so that they may come to a more conscious and deliberate choice.

Moreover, in this model there is no one answer for each question. Many questions remain open as a challenge to struggle further with them and every answer raises a new question. It is not because there is no ready answer that the questions raised by children, adolescents and adults should not be taken seriously. Rather, learning to deal with questions in the catechism is a felt need of great importance. Catechesis is a process of searching whereby everyone can learn something and where diversity in the group acts as a stimulus to question one's own position. Nobody has arrived, no one has a monopoly on 'the truth'. This actually means that catechesis always has a catechumenal and a mystagogical character ${ }^{10}$ : it leads to constantly deeper levels without ever pretending to have 'said everything' on the matter. "The core of the modernized 'mystagogical approach' is that it deliberately begins the catechetical learning process with an interpretation of life (and transcendental) experiences so that it is not external knowledge but the actual living out of deeper faith insights that is paramount"11. Catechesis with a permanent catechumenal and mystagogical character assumes a culture of formation in which believers and other interested people are constantly encouraged to go further into the faith. It is therefore necessary that the formation is sufficiently disseminated via internet, magazines and so forth. To this end some encouraging steps have been undertaken in recent years, but there is still much work to do.

Many people today no longer believe in 'tradition' as a monolithic whole but rather assemble their own set of fragments as a type of 'bundled together faith' ${ }^{12}$. Such a bundled together faith is often viewed rather negatively by the two previous models. This third model, however, offers people an opportunity to learn and to make conscious choices for themselves. People often set themselves against certain presentations and choose only for a kind of vague 'transcendentfaith'. This is the case today among children and certainly among young people. Such 'resisting' can be seen as a form of 'negative theology' that should not necessarily be judged as a negative development in itself but as something that can offer a new dynamic to the religious search ${ }^{13}$.

\footnotetext{
${ }^{10} \mathrm{H}$. van den Bosch, De toekomst van de parochiecatechese, op. cit., p. 132.

${ }^{11}$ Ibid., p. 131.

${ }^{12}$ Ibid., p. 129.

${ }^{13}$ Ibid., p. 135.
} 
This does of course assume that it is possible to break the 'spiral of silence' about faith ${ }^{14}$. In Flemish society faith seems to be taboo for many people. There is a 'culture of shame' about being involved in religion. However, whenever religious leaders, catechists and pastoral workers give value and recognition to their faith, and whenever they approach the topic openly and dare to speak about their own concerns and about what 'faith' means to them, then openings can be created for others to break out of this 'spiral of silence'. This presupposes some 'courage' and 'trust' to let the outside world see some of what is going on in a person's 'inside'. However a certain caution needs to be raised against indulging a type of expressive exhibitionism since talking about one's own beliefs can never become an end in itself. Instead they must be framed within a joint learning process that is both a learning 'from' and 'with' the other as well as a learning from the tradition.

This third model presented here has grown out of the theory of religious education and the plurality that exists in the school classrooms. And just as there are students present in the classroom who have varying views and degrees of involvement in the Christian faith and the Church, so there are also sometimes substantial differences in the views expressed in the catechesis groups. One can of course expect a certain 'involvement' with faith since catechesis presupposes certain choices, but even within that basic orientation many variants can be distinguished which need to be considered in their own right. Neither the aim nor the starting point of catechesis can be the same for everyone. This implies that the tension between the 'elite-church' and the 'service-church' cannot be settled in favor of one over the other, but that a model needs to be applied whereby both those who are looking for a deepening of their faith as well as those who are just asking for a short 'service' can feel comfortable. A key feature of such a model is that diversity is seen as an incentive and not as the applying of a handbrake ${ }^{15}$.

Such a hermeneutical approach to catechesis does not depart completely from the idea that young people are 'blank sheets', as they are often represented today. Due to the secularization of the culture and the conclusion that religion is much less prominent in our society than a few decades ago, many think that young people now have little background in Christianity and so are theoretically much more open to learn about the faith. This is only partly true. Our culture still contains (semi-)

${ }^{14}$ R. Köcher, Die Entwicklung von Religiosität und Kirchlichkeit seit dem Zweiten Weltkrieg bis heute, „Diakonia” 19 (1988), p. 37; U. Schmälzle, Religiöse Erziehung in der Familie, in: H.-G. Ziebertz \& W. Simon (eds.), Bilanz der Religionspädagogik, Düsseldorf 1995, Patmos, p. 375.

${ }^{15}$ See W. Tzscheetzsch, Sakramentenpastoral im Wandel, in: G. Biemer (ed.), Symbole des Glaubens leben. Symbole des Lebens glauben. Sakramentenkatechese als Lernprozeß. Taufe, Firmung, Eucharistie, Ostfildern 1999, Schwabenverlag, p. 96. 
religious elements and symbols, like the organization of holidays, the Christmas atmosphere in the streets, religious education in schools, public broadcasts on radio and $\mathrm{TV}$, the physical presence of churches in the streets and so on. Young people are not completely independent of a tradition, they carry pieces of it with them through what they hear and see in their surroundings. These pieces, these loose elements provide clues for catechesis. There has been talked in religious pedagogy recently about 'abduction'16 instead of deduction and induction. Abduction is a movement away from what is there, not a bringing in of something completely new (deduction) nor a derivation of something completely new from something already existing (induction). It is, on the contrary, a movement from the fragments of the tradition to larger wholes of interpretation and vice-versa. Should youngsters be 'blank sheets', they would not be taken seriously in their 'ability'. They would be regarded as a wooden barrel that could easily be filled up rather than as a vessel that already has something in it and which has the capability itself to determine the taste of what may be added.

In this third model people are responsible for their own learning process. What needs to be learned is not fixed in advance. In terms of the practical application of catechetical learning this means that people can signal at the beginning and at the end of a session (or a series of sessions) what they would like to learn for themselves and what they have learned. It's not about what others think should be known but what they themselves want to learn. It is the art of catechesis to respond to the real questions that children, adolescents and adults have.

It is clear that in this model much more is expected of the catechist as well as of the participants in the catechism. Both the content and the teaching formation of catechists is therefore a priority with this model.

\subsection{The theological vision of the hermeneutical model regarding faith, culture and catechism}

In ourview the hermeneutical approach to catechesis offers the best opportunities for the future, not only because we believe that through the confrontation of faith and culture both poles will highly 'benefit', but also because this view has the best credentials theologically.

From an optimistic belief in creation, Christians hold that people - made in the image of God - have their own philosophical and life skills as well as a fundamental openness to receive the Christian message. The hermeneutical

${ }^{16}$ H.-G. Ziebertz, S. Heil \& A. Prokopf, Abduktive Korrelation. Religionspädagogische Konzeption, Methodologie und Professionalität im interdisziplinären Dialog, Münster 2003, Lit Verlag. 
model as applied to catechesis is premised on there being such an openness in people and on a belief in their abilities. Catechesis is a joint search and learning process on the basis of both shared and disputed interpretations. The deductive model reflects a more limited confidence in people's own philosophical skills because all the focus is laid on what is handed down from the 'outside'. In the inductive model, an explicitly Christian reflection is often omitted which likewise reveals a limited belief in the philosophical skills of people.

From the point of view of incarnational faith (the belief that God became man in Jesus of Nazareth), it is important not to see God and faith as something 'foreign' in relation to the world but to take the world completely seriously. The life-view of so many people today, their needs, their questions, their vision regarding humanity and the world must all receive attention within the catechetical process but without equating this 'life experience' with 'faith' or immediately giving it a Christian form. In that case justice is not done to either faith or people's experiences. Christians believe that God and humanity do not coincide, but that God became human. From the Christian perspective humanity did not become God. These importantly nuanced beliefs can be very inspiring for catechetical approaches. It is therefore unfair to categorize the human experience as 'Christian' without due caution be taken, although this does not mean that there is no interaction between 'experience' and 'belief'.

The hermeneutical model of catechesis is also based on a belief in the Spirit of Christ, a pneumatological belief. Catechesis is a process of the Spirit whereby freedom and creativity receive the necessary space. In a hermeneutical learning process where different views are brought together in confrontation, this belief in the power of the Spirit who guides the process is of great importance. The Christian tradition itself can be seen as a continuous hermeneutical process driven by the Spirit ${ }^{17}$. The process of passing the elements of tradition down through the generations is marked by constant reinterpretation and it is precisely at those points that Christians recognize the power of the Spirit. Tradition is not a rigid assemblage that should be stored as a finished product but nor is it an optional extra that you can simply let fall by the wayside. On the contrary, it is a valuable fruit of the Spirit. In hermeneutical catechesis justice is done to this vision.

The hermeneutical approach to catechesis can also be supported from the point of view of Christian eschatological faith. The idea of the 'eschatological reserve' calls people to be critical towards every earthly reality and to do so by questioning the very belief in the Kingdom of God. No earthly reality is final. A critical confrontation between elements of experience and elements of belief

\footnotetext{
${ }^{17}$ J. Haers, Het avontuur van de traditie, Averbode 1999, Altiora.
} 
in the catechetical process seems appropriate from this standpoint. Each found 'agreement', 'harmony' or 'correlation' should again be critically questioned. "We cannot pretend we know everything and that we are already living in the full glory", writes Wiel Logister in relation to the idea of the eschatological proviso ${ }^{18}$. Furthermore, visions based on belief are never final. The theological idea of Deus semper maior, that God is always greater, challenges all participants in the catechetical process to build a searching, self-perfecting, but never finished or complete faith perspective. From an eschatological faith perspective Christians can live with the certainty that catechetical efforts are not wasted, but at the same time they can realize that not everything depends on them. Construction work on the bridge between faith and culture must not be suspended, but neither can it be completed tomorrow by people working on their own. The probability that it may occasionally become a very shaky bridge remains high. From an eschatological perspective, however, the belief that at some point a strong bridge will appear makes being occupied with catechetical matters very worthwhile.

\section{Lifelong and lifewide learning}

Besides the question of the content and method of catechesis, there are many questions today around the organization and the place of catechesis. In what follows we will treat the theme of 'networks' and a person's 'age' as one whole.

\subsection{Vertical Networks}

\section{a) Child and adult catechesis}

Sometimes the question is asked: 'Which should take priority ${ }^{19}$, adult catechesis or child catechesis?'. We believe this is a false dilemma for offering children's catechesis without an exciting adult catechesis is not enough, nor is having an adult catechesis without a children's one. Why do both belong together? Because adults and children learn from as well as teach each other. Children can further stimulate adults who are active with their faith by asking them questions or by talking about the catechism at home and so on. Adults can of course encourage children to further develop a believing outlook on life since they have a major

${ }^{18}$ W. Logister, Aspecten van waarheid in de christelijke traditie, in: W. Logister et al. (eds.), Echt waar. Over theologische waarheid, Averbode 2003, Altiora, Averbode., p. 137.

19 Johannes-Paulus II, Over de catechese in onze tijd. Apostolische aansporing Catechesi Tradendae, Brussel 1980, Licap, p. 33 (nr. 43); Congregatie voor de Clerus, Algemeen directorium voor de catechese, “Eén twee één. Kerkelijke documentatie” 28 (1998) nr. 27, p. 65 (nr. 171). 
impact on them and, practically speaking, children are often unable to participate in catechesis without the support of their parents. If the focus is only on adults then it only gives the impression that the faith is something that is 'too difficult for children' and does not take them seriously enough. Anyone who actually gives catechesis can certainly testify how young children can also ask particularly difficult questions. The recent literature on German religious education primarily deals with the subject of "child theology"20. In this approach children are seen as little theologians who possess their own vision of the faith. For children faith is important while they are still children and not just for later life when they are grown up. Even at that young age children raise important theological questions and openly express their insights into the faith.

On the other hand, whenever child-centered catechesis is placed central stage then it becomes easy to say that faith is only something 'for children' with the result that adults often do not take it seriously. At the basis of the question regarding the priority of either children or adult catechesis is a dichotomy between adults and children that has grown since the Enlightenment and which still plays an important role in our society. Educators talk about the 'pedagogization of society'21, where children, as it were, are placed on 'pedagogical islands' (such as school, sports clubs, music, catechesis group, TV programs [aimed at children] and so on) that promote isolated learning. Today, adults are also expected to 'learn': lifelong and life-wide learning has become a key phrase. It is clear that an alternative to 'islandthinking' is now required in an increasingly complex society. Various forms of 'intergenerational catechesis' are therefore of particular interest. This does not only mean that the catechism should be focused on different generations but that the

${ }^{20}$ The thematized edition 'Waar blijven onze kinderen? Een pastorale en katechetische refl ectie op het kind als zelfstandig subject', in the journal "Concilium” 32 (1996) Nr 2; A.A. Bucher, Gottesvorstellungen in der kindliche Entwicklung, "Lebendige Katechese” 13 (1991), p. 19-24; A.A. Bucher, Gott ist ein Mensch für mich... Gottesbilder im Grundschulalter, "Katechetische Blätter” 116 (1991), p. 331-335; S. Klein, Gottesbilder von Mädchen. Bilder und Gespräche als Zugänge zur kindlichen religiösen Vorstellungswelt, Stuttgart 2000, Kohlhammer; S. Eckerle, R. Gleiß, M. Otterbach, W. Schwendemann, Gott der Kinder. Ein Forschungsprojekt zu Bildern und Gottesvorstellungen von Kinderen, Münster 2001, LIT Verlag; G. Büttner \& J. Thierfelder (eds.), Trug Jesus Sandalen? Kinder und Jugendliche sehen Jesus Christus, Göttingen 2001, Vandenhoeck \& Ruprecht; M.-T. Wacker \& R. With, Gottes Kinder (Jahrbuch für Biblische Theologie 17), Neukirchen-Vluyn 2002, Neukirchner Verlag; A.A. Bucher et al. (eds.), Mittendrin ist Gott. Kinder denken nach über Gott, Leben und Tod (Jahrbuch für Kindertheologie 1), Stuttgart 2002, Calwer; A.A. Bucher et al. (eds.), Im Himmelreich ist kein Sauer. Kinder als Exegeten (Jahrbuch für Kindertheologie) Stuttgart 2003, Calwer; B.J. Miller-McLemore, Let the Children Come. Reimagining Childhood from a Christian Perspective, San Francisco 2003, Jossey-Bass.

${ }^{21} \mathrm{M}$. Depaepe, De pedagogisering achterna. Aanzet tot een genealogie van de pedagogische mentaliteit in de voorbije 250 jaar, Leuven 1998, Peeters. 
different generations can also learn from each other. It is also termed "reciprocal faith learning" ${ }^{22}$. Children can learn from adults but adults can also certainly learn from children. Such intergenerational, reciprocal faith learning can be fostered by family afternoons and evenings ${ }^{23}$, family celebrations, home assignments for parents and children and the like. One could also think of initiatives involving children going to nursing homes to learn from the elderly about what faith can mean to them and where 'praying' is something that both children and the elderly can do together. By such initiatives the elderly, who are often more than delighted with the children, can learn a lot from the younger generation.

\section{b) Looking for suitable starting points for parents and children}

Intergenerational learning is a major challenge for catechesis in Belgium. Catechesis is not something to be restricted to a certain age or linked to a certain moment. Catechesis is a process of 'lifelong learning', where different generations simultaneously learn both with and from each other. There are, though, still 'preferred moments' for catechesis to take place at. Such as the sacraments of initiation which can bring a renewed connection with the faith for both parents and children and for the wider church community. A majority of the population still opts for baptism, first communion and confirmation. This is not just a social phenomenon but in many cases carries a deeper background and significance. The Christian faith is often present somewhere in our context as an unconscious horizon without being thematized ${ }^{24}$. The sometimes vague idea of faith can come forth as a more conscious theme for discussion in response to the request for these sacraments of initiation. Consider the example of baptism where parents are directly confronted with the question: 'what do I want, what do we want for the child?', or at first communion which is an excellent opportunity for parents, children and the whole family to experience faith and the church. However all this requires having sufficiently accessible initiatives.

To reach the parents one must also ensure that the catechetical approach takes sufficient account of the family situation ${ }^{25}$. This means for example that it is best

${ }^{22}$ A.M. Lanser-Van der Velde, Geloven leren. Een theoretisch en empirisch onderzoek naar wederkerig geloofsleren, Kampen 2000, Kok; A. Lanser, Geloven leren. Een theoretisch en empirisch onderzoek naar wederkerig geloofsleren, ”Praktische Theologie” 29 (2002) Nr. 1, 127-142.

${ }^{23}$ See for example: T. Haas \& E. Färber, Von Schätzen, Perlen und anderen Köstlichkeiten. Katechetische Nachmittage für Kinder und Eltern als ,Schatztruhe', in: A. Biesinger \& H. Bendel (eds.), Gottesbeziehung in der Familie. Familienkatechetische Orientierungen von der Kindertaufe bis ins Jugendalter, Ostfildern 2000, Schwabenverlag, p. 287-294.

${ }^{24}$ H.G. Ziebertz, Religiöse Erziehung in der Familie im Kontext der Moderne, "Theologie und Glaube” 87 (1997), p. 379.

${ }^{25}$ M.F. Schomaker, Die Bedeutung der Familie in katechetischen Lernprozessen von Kindern. Eine inhaltsanalytische Untersuchung von Konzepten zur Hinführung der Kinder zu den 
not to send a letter that opens with the words 'Dear parents'. That could come across as painful to those who have suffered divorce, for example. Besides that it is also important to talk explicitly to the fathers and to ensure that a certain fatherly involvement in the religious education of their children is encouraged. We often notice that it is the mothers who primarily attend parent evenings with regard to first communion or confirmation and who are engaged with bringing up their children in the faith at home. Whenever fathers are also involved in catechesis, however, the chance decreases that faith is seen as something 'trivial' and it increases the likelihood that children become actively engaged with the faith themselves, according to recent empirical research ${ }^{26}$.

Intergenerational learning also requires space to be provided for the involvement of grandparents in catechesis. A lot of grandparents play an important role in offering family and child raising support for their children and grandchildren ${ }^{27}$. This is also true in the field of religious education. When young people were asked how often they talked about faith with certain persons it was the grandparents who scored relatively highly ${ }^{28}$. Perhaps there is an underexposed opportunity to encourage faith formation in the dialogue between grandparents and grandchildren. People could look for ways to organize 'grandparent evenings' within a parish, a church federation or a deanery. In addition, the 'content' of the faith and faith communication deserve special attention. What images of God or religious views on life do grandparents have? How can grandparents be stimulated to critically question their images concerning church, faith and God while keeping a certain resilience that is important in faith conversations, especially with the younger generations? How can dialogue be held with grandchildren ${ }^{29}$ ? Can the faith communication between grandparents and grandchildren be a way to stimulate faith conversations between parents and children and between grandparents and their children (who are parents)? How can the tensions and conflicts that exist

Sakramenten der Beichte und der Eucharistie, Münster 2002, Lit Verlag, p. 316.

${ }^{26}$ D. Pollefeyt et al., Godsdienstonderwijs uitgedaagd. Jongeren en (inter)levensbeschouwelijke vorming in gezin en onderwijs. Opzet, methode en resultaten van empirisch onderzoek bij leerkrachten rooms-katholieke godsdienst en leerlingen van de derde graad secundair onderwijs in Vlaanderen, Leuven 2004, Peeters.

${ }^{27}$ H. Van Crombrugge, Grootouders en de hedendaagse gezinnen, in L. Vandemeulebroecke, H. Van Crombrugge \& J. Gerris (eds.), Gezinspedagogiek. Deel I: Actuele thema's in onderzoek en praktijk, Leuven-Antwerpen 1999, Garant, p. 169. See also H. Van Crombrugge, De gezins- en opvoedingsondersteunende rol van grootouders, in: A. Marcoen (ed.), Grootouders. Tussen mogen en moeten, Leuven-Apeldoorn 1996, Garant, p. 69-82.

${ }^{28}$ D. Pollefeyt et al., Godsdienstonderwijs uitgedaagd, op. cit., p. 261 \& p. 273.

${ }^{29}$ See also: A. Arens, Grootouderschap en geloofsopvoeding. Een pleidooi voor een catechese met grootouders, “Rondom gezin” 15 (1994) Nr 2, p. 87-94. 
between the generations in terms of perspective be dealt with? These themes could especially be addressed during evenings aimed at grandparents and parents.

Because intergenerational learning should be possible and because parents should get involved in the catechetical process, both parents and children ought to be addressed in areas in which they have a certain affinity. Catechesis also has a need for a sufficiently differentiated approach regarding parents and children. Every parent and every child has his or her own competencies all of which can contribute to learning with and from each other in the family and in the parish. Parents may be asked to give logistical support for an afternoon of catechesis, to provide transport, to make decorations at home for the church together with the children, to enter into concrete conversations with children or other parents, to write a report for the parish newsletter and so on. Involvement can be expressed in many ways and that is where parishes can openly seek to create real intergenerational learning. Voluntary parent evenings, possibly organized by different parishes together, or even the partial attendance of a parent evening could also be opportunities for people to speak to others from diverse backgrounds and interests.

In various dioceses many initiatives are currently developing that seek to bring about 'intergenerational catechesis'. Take for example a Sunday with a joint celebration for parents, children, confirmants, altar servers, parishioners and others. A focus on liturgically strong moments, family celebrations, confirmation activities and so on, all in which the elderly can take a full and active part, really helps make intergenerational catechesis come alive. Sometimes parents are invited to the end of an afternoon's catechesis and catechists and children relate what they had worked on that day in a playful way. Such initiatives deserve the necessary support from other parishes and increased publicity. Many appropriate models can be described and disseminated through printed publications, or the internet so that one parish's good experience can have positive repercussions elsewhere.

\section{c) Gaps in what catechesis can offer different age groups}

Whenever catechesis is exclusively coupled to the sacraments of initiation it gets a 'momentary' character. Many will feel at ease with that but others are looking for more 'learning opportunities' or are open for when such initiatives are offered. In some places in Flanders and Brussels people offer 'bridging catechesis'. This means that catechesis is not only something that takes place on the occasion of first communion or confirmation but also during the intervening years. This is an initiative that deserves praise because that way catechesis takes on the character of 'lifelong learning', even though in this instance it does not go beyond the confines of childhood. Catechesis is not something of the moment 
but an ongoing process which is aimed at children and young people as such and is not only 'sacrament'-centered. Faith is then seen as something important to everyday life and not only in regard to receiving a sacrament.

There is a noticeable gap in the provision of faith formation for young adults between the ages of twenty-five and thirty-five. For younger people all kinds of initiatives are organized while for the older generation there are more traditional organizations. For people between twenty-five and thirty-five there is sometimes a short 'pre-marital counselling' when they choose to marry, but beyond that there is often little possibility for having a 'faith talk'. Another shortcoming lies with the catechesis for young children. Between baptism and first communion often very little happens in terms of faith formation - except possibly in the nursery or at home with highly motivated parents. The oft promoted image is that children under 6-7 years of age are really too young to be interested in faith. Do we not underestimate the children then? Is it not just those young children from 3 to 4 years old who are particularly sensitive to the mystery inherent to reality? It would be good, for example, if parishes, associations, local committees, and the regional and diocesan catechetical commissions responsible for the religious education of young children were to develop approaches for family afternoons in a parish and for parents at home ${ }^{30}$.

If we take the point of view that catechesis or faith communication is something unconnected to one age group or specific moment then we can partly limit our frustration that confirmation is often nothing more than a farewell ritual to the church. It is not because twelve year old children no longer come to church that they shut all the doors for the rest of their lives and that the catechism proved futile. Perhaps later in life new openings for faith and the church will come about. Moreover, it is good to point out that the aim of catechesis is not the same for everyone and that the 'success' of catechesis can certainly not be linked to the immediate after-choice of children in relation to faith and the church. What is important for children following catechesis, is that it gives them renewed energy to live their lives, that it touches them and makes them sensitive to the working of the Spirit and that it leaves an openness in them to possibly take up with the faith again in the development of a 'religious autobiography'.

Catechesis as 'lifelong learning' is also partly a response to the criticism leveled at the psycho-genetic approach to catechesis. Whenever faith formation is linked to the age and psychogenetic development of children too exclusively, little attention is given to the real differences that exist between children, adolescents

${ }^{30}$ See the research by I. de Haan, Klein beginnen. Onderzoek onder ouders met jonge kinderen over geloven en opvoeden, Amsterdam 1999, Koppederaijer en Partners. 
and adults. Diversified catechesis, on the other hand, with its possibility of going deeper with all age groups is consistent with the 'religious autobiography' of people, that is, it sees their own faith development in ways not predetermined by specific factors (such as age or the school class in which one sits).

\subsection{Horizontal networks}

Pastors, those committed to the church and catechists very often point out that many confirmants or those taking their first communion no longer come to church the week after the big celebrations, even though the process may have involved intense preparations. Many find that frustrating and ask what is the point of it all? Catechesis seems to have become something instantaneous: it is picked up for the moment but it does not achieve integration within the whole of life.

We can characterize this phenomenon as 'partial identification'31. People today are not fully committed (even if they could be). This applies not only to the church but also to all other voluntary work. Individuals take on so many different roles that an 'identification' with a group or an association is not really desirable or possible - except to some extent. That reality also creates difficulties in finding (young) catechists.

How can these changes be handled? Several key terms that come to light in response to this challenge are: 'forming networks', 'project-based relationships', catechesis ad intra and ad extra. Here the concern to work 'connectedly' without being stifling remains central.

\section{a) Project-based relationships within the faith community}

In addition to forging links between generations on the vertical level, it is also a major challenge for the parish to create internal and external networks from out of a 'communio-vision'. Communio and communication are related to each other and promote one other. The lack of a vibrant faith community is felt by many as one of the main bottlenecks in catechesis. It is therefore important to find viable initiatives that can give 'life' and create 'community'.

Our society thrives on 'projects', short goal-directed initiatives. Such an approach can be criticized because of the sheer uncertainty regarding the future, yet there are also valuable aspects to it. In the short-term, dynamics are set in motion that can make things happen. No long-term commitment is asked of people because many are already so busy and there are also those who are hesitant and somewhat scared to fully rally behind an initiative. An example of this is participating in a pilgrimage. This is a short-term commitment that sometimes

\footnotetext{
${ }^{31} \mathrm{H}$. van den Bosch, De toekomst van de parochiecatechese, op. cit., p. 133.
} 
reaches people whom one would otherwise not see. It is therefore very important to take people seriously in their limited engagement. This requires an openness to various forms of commitment and involvement. Other examples of project work include: speaking to people about creating and maintaining a parish website, organizing a trip to visit Christmas nativity scenes with several parishes together, an annual family day or getting youth involved in the animation during catechesis weekends and so on.

These many separate initiatives should not exist independently of each other, but ought to have occasional points of contact (integration). This could be achieved for instance by meeting in the same premises as other associations do with their posters or calendars clearly visible so that people feel somewhat connected with the wider community. There are numerous other examples of short-term projects that forge relationships within the church community. Imagine getting confirmants or the elderly jointly involved within a Flemish 'Broederlijk Delen' (literallly: 'Brotherly Sharing') project. This would allow the catechists and the others in the Broederlijk Delen group to get to know each other which may in turn help to create sensitivity towards each other's efforts and concerns. Another possibility would be to hang up a calendar up in the church showing the various initiatives to be undertaken and to set up a similar calendar via the parish website and the parish newsletter. This would help people to become aware of the fact that they are part of a larger whole. At the same time, this would require the leaders to have an attitude that does not assume that people in the liturgy workgroup deliver a more important work than those who accompany the seniors or the youth leaders, but that everyone in his or her own way contributes to the community which is actually pieced together like a beautiful mosaic.

Catechesis often receives a limited role within the organization of the parish. This could be due to the fact that the Catholic Church traditionally upholds a celebratory culture rather than a teaching culture ${ }^{32}$. In the practical organization of the parish, the liturgy often receives a lot more attention than parish catechesis or the diaconate. Parishes are confronted with the question whether they want to appreciate and are able to appreciate the responsibility of 'faith communication' by including it more openly within structures that do not directly address this issue. This could be done, for example, by highlighting it in the homily during services or by providing appropriate training and support at different levels and bringing the expertise from the various workgroups within the parish together, for example by offering support to the leaders in the youth work who may occasionally do something based around 'life views'. In some places leaders of other groups in

\footnotetext{
${ }^{32}$ Ibid., p. 134.
} 
the parish are brought in (for example to give the homily) during Eucharistic celebrations for the confirmants so that children and parents can learn more about diversity within the parish. In these and in many other ways 'community' can grow out of diversity. Catechetical aspects can be detected and supported in the different areas of the life of a faith community, however, without this 'wealth of faith' being reduced to 'catechesis' and without proper catechesis being reduced to 'catechetical aspects'.

\section{b) Catechesis inside and outside its own circle}

To forge project based links within a small community seems feasible ${ }^{33}$, but a greater challenge is seen in making the link with the wider church community, which many now regard as absent. Although the world has become a village, this still seems not to be the case when it comes to the 'church'. Here too the Belgian church has an important task to fulfill in terms of working on its image. But steps could also be taken at the local level to create networks with the wider church community, for example through exchange projects (such as the Erasmus/ Socrates exchange programmes, though not in this case for the benefit of students but for children involved with church, adolescents and adults) or by inviting guest speakers, by running initiatives associated with missionary work (e.g. in connection with the mission month, epiphany singing in many parishes ...) and so on.

The church also has a responsibility to the outside world. When the church folds in on itself and hopes that people will come to her and then responds to the people who do not with an attitude of incomprehension, it will eventually become nothing but a small group of so-called 'high churchers' who all share a similar but enclosed vision. For the church an exclusive focus ad intra is undesirable. For the 'outsiders or peripheral church goers' a folding in of the church on itself is also not advantageous. Along with Anton Houtepen we would say: "Whoever sells the entrance tickets to the church exclusively to those for whom faith is assured, is blocking the way to God"34 ${ }^{\prime 3}$. As Jesus went out to the people, so parish communities and the church as a whole are expected to 'act on the move'.

It is not always easy for many children and parents to juggle between, say, the 'local football club' and the 'catechesis'. Should children's hobbies always make way for catechesis or ought catechesis to give way to the hobbies? When the question is asked in this way the only way out seems to be a constant struggle

${ }^{33}$ Ibid., p. 137.

${ }^{34}$ A.W.J. Houtepen, Geloven samen met anderen, in: H. van Hout (ed.), Geloven in de randstad (DPC-Bundel 3), Diocesaan Pastoraal Centrum van het bisdom Rotterdam, Rotterdam, p. 85. Cited in: H. van den Bosch, De toekomst van de parochiecatechese, op. cit., p. 134. 
between the different perspectives. Maybe a third alternative is possible where for instance catechesis and football, to continue the example, can work together. Is it not conceivable that a catechist could give catechism at a time when there is no soccer practice or game on, or if that is not possible, that he or she could then make flexible arrangements with other parishes? Is it not possible to take adequate diversity and flexibility into account in the practical organization of the catechesis and to see this not only as a 'sacrifice' and a 'putting out of oneself' on behalf of the catechist, but as an enrichment of the whole process? One example would be to have a family-day catechesis that finishes with a game or sporting event, e.g. a football match with parents, children, catechists and those committed to the parish. Such an approach shows that faith is not something separate from life. People who otherwise experience little involvement might in fact be present at such an initiative and might meet with the children's catechist. Children who play a musical instrument could be given space within the catechism or within the services to show others their talent. Such 'acting on the move' means more than 'forming networks' and 'cooperative development'. It also means having the courage as faith communities to be present in the media, through local radio for example. It also means daring to be a Christian at work, in the associations with which one is connected, at home in the family and so on. It is daring to set up a stand at an annual or Christmas market, for example, that is not shy of advertising a Christian reflection.

This 'stepping out' or taking up position on the 'agora' or market place requires that church people are courageous and that they can empathize with others ${ }^{35}$, with those who are not so close to the church. Moreover, it requires that they are willing to let themselves be challenged by the logic of the 'agora'. Where possible, the boundary between the 'inside' and the 'outside' of the church ought to become more vague ${ }^{36}$ and more cross-pollination should be encouraged to take place.

\section{Looking for catechists}

There is much to do at the parish level - such as 'expanding networks', 'connecting with parents', 'creating openness' and so on. Beyond this, we would further bring the reader's attention to three points regarding the catechist and two basic attitudes concerning the shaping of catechesis. A first priority within today's parish catechesis is the search for catechists and catechetical assistants. Catechesis and faith communication is of course not solely dependent upon the

\footnotetext{
${ }^{35}$ H. van den Bosch, De toekomst van de parochiecatechese, op. cit., p. 134.

${ }^{36}$ Ibidem.
} 
catechist, but without sufficient and skilled catechists it becomes very difficult, at least on the formal, structured level. However, whenever catechesis comes to be seen as a central part of the parish community this need can be at least partially met. This would include getting more project-based collaborative approaches up and running and by communicating more openly about the catechesis (in the church, via the internet, through the parish newsletter etc.). It is also important to speak with the parents - not necessarily to see them as catechists themselves for the long haul, but perhaps as casual catechists who are there for one meeting or for a six month period, or as those who could offer practical assistance. In some parishes there are one or two catechetical leaders and the group of 'catechists' continues to be renewed every year by the parents of the children. This offers new perspectives for catechesis and for the family life of the parents themselves. Undoubtedly this proposal may run into some practical problems like finding sufficiently strong leaders, or raising issues around the formation of the parents, or the possibility of a lack of continuity and creativity due to the short-term commitment and such like. But despite potential difficulties this approach could bring much added value to many different situations. In order to appeal to people and to motivate them it is of course essential to have on-going and good support from the diocesan or regional services.

Finding catechists is one thing. Forming them is quite another challenge. For many people it is often asking too much to regularly attend training sessions which involve a drive of between 30 to 60 minutes. Catechist Days often attract many people, but it remains only a small percentage in terms of the total amount of catechists it actually delivers. The difficult task is how to reach all the catechists and give them minimal training. Much can be achieved by having good team meetings and by offering good guidance and support where necessary by those in charge and by pastors. But undoubtedly there is still much work to be done in terms of mental attitude. Giving catechesis to children is important and definitely not 'easy' even though 'it's just children'. Giving catechesis to adults also requires mastering some skills that can be learned and which can increase the joy of giving it. Parishes should insist on training for volunteers especially when it can be made clear that the training offers added value to the catechist as a person and not only in terms of organizing the catechesis. A diversified offer of training should be an important priority. Developing websites for catechists would also be useful .

In addition to the good teaching and theological formation of catechists, one of the more delicate issues is the question of the catechist's faith and his or her church involvement. A catechist is a role model and thus has a responsibility. But the spirituality of the catechist can be described in accordance with the three 
models mentioned at the beginning of this text: he or she may place an emphasis on tradition, an emphasis on personal experience or be critical-interpretive with an equal emphasis on experience and tradition. In this third model truth is seen more as a vision of the future ${ }^{37}$. Here the faith of a catechist is not be seen as 'finished' and it is desirable that the catechist continually questions and challenges him or her self by means of the content of the catechesis and by the interaction that occurs. In this way catechesis becomes an interactive enrichment both for the one who 'gives' it as for the one who 'follows' it.

What is more, any person who in some way has a certain feeling in regard to faith and the church could equally be a catechist as well as a catechumen. In principle anyone can give catechesis as well as follow it precisely because it is a collective search for what people consider 'true' and 'good'. It thus encourages a constant learning both with and from one other.

Having good catechists is therefore as important as offering good support to catechists but above all it is important that 'anxiety' does not predominate. "We must take care to avoid the understandable but fatal urge to want to avert shyness in regards to content or its seeming unmanageableness by choosing for a misplaced literalism"38. The point being made here is the need to bring to light people's questions about life and to thematise this in the catechesis in a critical hermeneutical confrontation with the content of the Christian tradition. Solely conveying information or the amount of knowledge held by the catechist or catechumens will not help the catechism, the church or the faith move forward. But the contextual rootedness of faith in people's experiences and the highlighting of the relevance of faith for everyday life will. To realize that we need a catechism with guts, a catechism that is 'inside out', a catechesis that constantly questions and reinterprets itself.

\section{Catechesis in the picture? Between giving and receiving}

We can see quite a few of the characteristics of good parish catechesis that we have described above in the symbolically pictured artwork by Francis Bernard Dickee, entitled Out of Reach. Daughters of Eve which is located in the Bridgeman Art Library in London.

${ }^{37}$ I. Cornu \& D. Pollefeyt, Religieus opvoeden tussen openheid en geslotenheid. Bijbels geloof in een babelse wereld, op. cit., p. 56-58.

${ }^{38} \mathrm{H}$. van den Bosch, De toekomst van de parochiecatechese, op. cit., p. 137. 


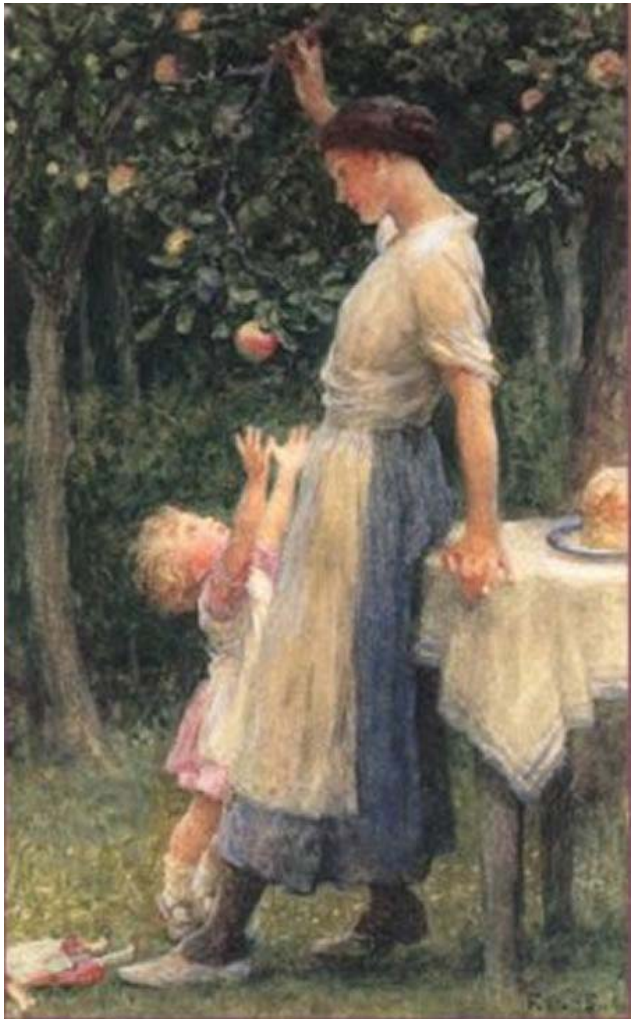

This image can provide an illustration of some key characteristics of good catechesis. At the same time the picture also has its limits. We see a mother offering her daughter an apple. She does not place the apple directly into the hands of her daughter but instead lowers the branch on which the apple is so that the daughter, standing on the tips of her toes, can take it herself. This can be likened to an image of a catechist who gives and offers various elements to adults or children by bringing them closer to them and by taking account of where they are at. As the mother in the painting responds to the desire of the child for the apple, so it is likewise a challenge for the catechist to respond to the desires of the people to be formed in the faith. Catechesis is not simply giving the apple into a person's hand. Instead it requires a form of active learning whereby participants are invited to stretch themselves and to grow. We could ask whether the child in the painting is not also extending her arms in order to be picked up by the mother. The image clearly shows us the importance of relationship. The personal relationship between catechists and catechumens is also of great significance for catechesis. Further, the painting depicts the bowing branch which can be viewed as an image of the (re) 
contextualization of faith. In different contexts and at different moments faith can be translated in different ways and take on a different shape, and as such it is not a static, immutable whole. The family context in particular offers opportunities to experience an initiation into the faith. The elements of everyday family life in the painting such as the mother's apron, the bread on the table and the child's doll evoke this fertile context of daily faith communication. The painting illustrates how catechesis in daily family life can actually enable 'revelation' to happen. In the painting the attention of the child is suddenly drawn to the apple while the doll that the girl was playing with is dropped to the ground and left there. Her play is interrupted. Interestingly the mother is leaning on the table. She does not spend all her strength on pulling down the branch but also takes care of herself ${ }^{39}$. Leaning on the table can be interpreted as an image of reliance on tradition or on the wider church community. The bread on the table near the mother may also be seen as a symbol for the connectedness of catechesis with the Eucharist.

Such a symbolic interpretation of this painting and the search for similarities with a certain perspective on catechesis speaks of a correlative relationship. We can, of course, move beyond the correlation and the search for 'harmony' between the painting and the images it evokes to a stress on the shortcomings instead. In the painting, for example, it is clear that the child does not enjoy the act of giving. In catechesis, however, the child must be encouraged to give and not only receive. Moreover, the catechist can actually draw strength from the child's own giving too and not just from the tradition (cf. the leaning on the table). The painting, when taken as the only picture of catechesis, also carries other restrictions with it. The mother-child relationship is indeed important for faith formation, but the father should not be missed out (as he is in the picture), and horizontal networking among contemporaries is likewise of importance. Furthermore, seeing the apple as an image for what is passed on in catechesis seems to suggest that the 'tradition' or 'faith' is finished when it is given to the catechumens as a perfect whole. That is certainly not the case in a hermeneutical approach to catechesis, as we have previously shown. The challenge today is that there is not just one apple tree with fruit on it that appeals to a child, but many different trees all bearing delicious fruit. Christianity is not the only religion in our society whose fruit people want to taste - that is if they want to taste it at all. In addition to these relevant issues which are absent from the painting, there is yet another aspect which, although it is present in the painting, tells us how catechesis ought not to be. The title of the artwork 'Daughters of Eve' is indicative of the Fall. Within catechesis the Fall

${ }^{39}$ For the interpretation regarding leaning on the table, see also: B.J. Miller-McLemore, Also a Mother. Work and Family as a Theological Dilemma, Nashville 1994, Abingdon Press, p. 123. 
could be seen as representing the danger of an engineered faith. Whenever one sees catechesis as the kneading of children, adolescents or adults, or whenever one thinks that one holds the keys to catechetical 'success' firmly in hand, then one has surely fallen and is guilty of pride. The image of Mary with her accessability and openness to God's message and grace is perhaps better suited as a metaphor for the catechist. Belief in grace can help combat a catechetical approach that is cramped, fearful or even fanatical.

\section{Bibliography}

Dillen A., Religious Participation of Children as Active Subjects: toward a hermeneutical-communicative model of religious education in families with young children, "International Journal of Childrens Spirituality" 12 (2007) Nr 1, p. 37-49.

Dillen A., Hermeneutics in Real Life. Practical Theology in Flanders (Belgium), "International Journal of Practical Theology" 12 (2008) Nr 2, p. 357-387.

Dillen A., Pollefeyt D., La place du constructivisme dans la catéchèse contemporaine, "Lumen vitae: revue internationale de catéchèse et de pastorale” 60 (2005) Nr 3, p. 261-278.

Pollefeyt, D., Belgium: the Hermeneutical-Communicative Model, in: H. Ziebertz (ed.), How Teachers in Europe Teach Religion, Berlin 2009, Lit Verlag, p. 31-44.

Pollefeyt D., Difference Matters. A Hermeneutic-Communicative Concept of Didactics of Religion, "Journal of Religious Education” 56 (2008) Nr 1, p. 9-17.

Pollefeyt D., Newcomers at the Source. When Youngsters Listen to the Church on the Future of Youth Ministry, "Bulletin European Society for Catholic Theology” 16 (2005) Nr 2, p. 48-59.

Pollefeyt D., Bieringer R.,The Role of the Bible in Religious Education Reconsidered: Risks and Challenges in Teaching the Bible, in: Bieringer R., Elsbernd M. (eds.), Normativity of the Future: Reading Biblical and Other Authoritative Texts in an Eschatological Perspective, Leuven-Paris-Dudley 2009, Leuven University Press - Peeters, p. 377-402.

Pollefeyt D., Lombaerts, H., Hermeneutics and Religious Education, Leuven 2004, Leuven University Press - Peeters. 